\title{
Management of false wire worm, Gonocephalum beetle (Tenebrionidae: coleoptera) in chickpea raised under residual moisture conditions
}

\author{
R. M. Wadaskar* and A.N. Patil \\ Pulses Research Unit, Dr. Panjabrao Deshmukh Krishi Vidyapeeth, Akola- 444104 (Maharashtra), INDIA \\ *Corresponding author. E-mail: rahulwadaskar@gmail.com \\ Received: January 05, 2016; Revised received: April 27, 2016; Accepted: July 08, 2016
}

\begin{abstract}
False wire worm, Gonocephalum indicum, incidence was observed for the first time in severe form in Rabi 2008-09 on chickpea, confined to saline tracts of Vidarbha (MS). Gonocephalum adults inflicts injury near collar region of chickpea resulting in collapsing and drying of plants translating into re-sowing of crop due to poor plant stand. Field study revealed $5.8-32.3 \%$ damaged plants with lowest damage in Module 9 (Seed treatment with clothianidin $2 \mathrm{gm} / \mathrm{kg}$ seed + spaying of chlorpyriphos $2 \mathrm{ml} /$ liter water 20 days after crop emergence), Module 10 (Application of phorate granules $10 \mathrm{~kg} / \mathrm{ha}$ at sowing + spraying of chlorpyriphos $2 \mathrm{ml} /$ liter water 20 days after crop emergence) and Module 11(Seed treatment with clothianidin $2 \mathrm{gm} / \mathrm{kg}$ seed + application of clothianidin granules 200 $\mathrm{gm} / \mathrm{ha} 20$ days after crop emergence) with 5.8,6.2 and $8.7 \%$ affected plants. The \% drying of plants due to injury was in the range of $4.3-21.6 \%$ with lowest in Module 11, Module 10 and Module 9 with 4.3, 6.0 and $6.2 \%$ drying of plants, respectively. Superiority of Module 9 (20.4 q/ha) and Module 11 (19.7 q/ha) was evident in yield, whereas, lowest yield was observed in control plot $(13.2 \mathrm{q} / \mathrm{ha})$. Module 9 and Module 11 registered higher net returns of Rs. 13887 and Rs. 9948 per ha, respectively, whereas, Module 9 and Module 10 had highest ICBR of 1: 6.0 indicating the suitability of modules in terms of bioefficacy and cost effectiveness for the management of Gonocephalum in problematic area.
\end{abstract}

Keywords: Chickpea, False wireworm, Gonocephalum, Modules for management

\section{INTRODUCTION}

Gonocephalum beetle, false wire worm is basically a soil inhibiting beetle, restricted to decaying organic matter. The association of Gonocephalum sp. with various crops is reported in review. Gonocephalum sp. along with two other false wireworms were found damaging groundnut pods in Gujarat (Kapadia, 1994) in Andhra Pradesh (Reddy et al., 1992) and as an occasional pest of groundnut in sub-Saharan Africa (Umeh et al., 2001). G. simplex was the earliest described and most destructive species and is known to damage maize seedlings in South Africa (Drinkwater, 1999) also on tobacco (Blair, 1990), whereas, of the fourteen genera of soil-inhabiting Tenebrionidae in maize fields in South Africa Somaticus and Gonocephalum, were most common (Drinkwater, 1989). Gonocephalum was reported as pest of canola [rape] in Victoria and Upper South East of South Australia (Miles et al., 1997). In Andhra Pradesh, adults of Gonocephalum sp. were found in large numbers in pitfall traps installed in fields of mature mixed crops of groundnut and pigeonpea on irrigated black soil (vertisol). (Reddy et al., 1992), whereas, International Crop Research Institute for Semi Arid Tropics ICRISAT, Hyderabad have reported incidence of $G$. dorsogranosum on chickpea. Although, there are reports of Gonocephalum as a pest of pulses, oilseeds, cereals and vegetable crops in literature but it seldom cross the status of minor pest, But the incidence of Gonocephalum was observed for the first time in a severe form in Rabi 2008-09 on chickpea, critically confined to major chickpea growing saline tracts of vidarbha (MS). Since then it is a pest with regular appearance, although at varying intensity. The prevailing species of region was identified as $G$. indicum Karzab (Tenebrionidae: Coleoptera). The Gonocephalum life stages viz., egg, grub and pupal stage were confined to soil, whereas, adults were seen on ground damaging the crops. Adults prefer to hide in cracks and crevices during bright sunshine and were seen during early morning or at dusk near the crop. The Gonocephalum adults inflict the scooping up type of injury on tender chickpea plant stem near soil surface (collar region), resulting in collapsed plants of chickpea. Generally, the adults prefer early crop growth phase but was even observed on later stage, though on a lower intensity. The damaged seedlings in turn dry often translate into re- sowing of crop. Based on intensity, even up to $60 \%$ or more with one to two re-sowings are observed in chickpea raised on residual moisture.

The reports of resowing of crop due to higher damage to crop translating in poor crop stand are not uncommon. This invasive pest, which once was a minor pest has made it mandatory to take up plant protection measures. There is no specific recommendation for the management of Gonocephalum, except adhoc recom- 
mendation of application of phorate granule 10G @ 10 $\mathrm{kg} / \mathrm{ha}$ before sowing, thus, present study was carried out to evaluate the efficacy of different insecticide modules as well as their cost effectiveness so as to formulate the management strategy for Gonocephalum in chickpea.

\section{MATERIALS AND METHODS}

The evaluation of insecticide modules against false wireworm, Gonocephalum on chickpea was carried out at Pulses Research Unit, Dr. Panjabrao Deshmukh Krishi Vidyapeeth, Akola (MS) during Rabi 2010-11 to 2012-13. Taking into consideration the nature of damage and incidence interval it was felt necessary to evaluate efficacy of different insecticides in a module form. Twelve treatments (Table 1) replicated thrice were subjected to evaluation in randomized block design. The experiment was planned to compare the efficacy of seed treatment, application of insecticide granules in soil, foliar application of insecticides and combinations thereof to work out best possible module for the management of false wireworm in chickpea.

JAKI 9218 was used as test variety, with gross plot of $2.1 \times 4.2 \mathrm{~m}(7$ rows $)$ and net plot of $1.5 \times 4.0 \mathrm{~m}(5$ rows), sown at $30 \times 10 \mathrm{~cm}$. The crop was raised under rainfed condition with recommended package of practices and adoption of plant protection measures were as per the treatments. Foliar application of insecticides was made with knapsack sprayer (spray volume of 500 $\mathrm{L} / \mathrm{ha}$ ) as per the treatment details.

The efficacy of insecticide was attributed to $\%$ plants injured by Gonocephalum, 10 and 20 days after application of first and second treatment of the module. Similarly, observations on $\%$ plant drying due to Gonocephalum injury at 20 days after application of first and second treatment of the module was assessed. Total number of plants per meter row length (MRL) and plants affected by Gonocephalum were recorded to work out \% affected plants in various treatments, 10 and 20 days after application of treatments of the module. Net plot yield was extrapolated to per hectare yield. The total cost of plant protection comprised of prevailing market price of insecticides per ha, labour and sprayer charges. Net monetary realization of a treatment comprised of increase in yield as a function of treatment over control and prevailing market price. Net profit of treatment was worked out by deducting the total cost of plant protection from net monetary realization. Incremental cost benefit ratio (ICBR) was worked out as a ratio of net profit to the cost of plant protection, which exhibits the economic viability for cost effective management of Gonocephalum on chickpea.

\section{RESULTS AND DISCUSSION}

Per cent plants injured by Gonocephalum: 10 days after application of first treatment of the module: Per cent plants affected by Gonocephalum adults injury, ten days after application of first treat- ment of the module had a range of $4.1-19.4 \%$ (Table 2). The lowest damage was recorded in Module 4 (Application of phorate granules $10 \mathrm{~kg} / \mathrm{ha}$ at sowing) which in turn was at par with Module 3 (Application of clothianidin granules $200 \mathrm{gm} / \mathrm{ha}$ at sowing) with 4.1 and $5.0 \%$ plants injured by adults, respectively. Soil application of insecticides was superior over seed treatment modules. The control plot had highest percentage of (19.4\%) affected plants.

20 days after application of first treatment of the module: Plants affected with Gonocephalum adults, 20 days after application of first treatment of module was in the range of 5.9 to $27.7 \%$ (Table 2). The lowest damage was recorded in Module 4 (Application of phorate granules $10 \mathrm{~kg} / \mathrm{ha}$ at sowing) followed by Module 3 (Application of clothianidin granules 200 gm/ha at sowing) and Module 9 (Seed treatment with clothianidin $2 \mathrm{gm} / \mathrm{kg}$ seed) with 5.9, 6.4 and $9.6 \%$ affected plants, respectively, whereas, the control plot had highest percentage $(27.7 \%)$ of affected plants by Gonocephalum.

10 days after application of second treatment of the module: After application of second insecticide component of module the \% plants affected with Gonocephalum beetle injury was in the range of $2.2-22.8$ $\%$ (Table 3). The lowest damage was recorded in Module 10 (Application of phorate granules $10 \mathrm{~kg} / \mathrm{ha}$ at sowing + spaying of chlorpyriphos $2 \mathrm{ml} /$ liter water 20 days after crop emergence) with $2.2 \%$ affected plants and was significantly superior over rest. Application of Module 9 (Seed treatment with clothianidin $2 \mathrm{gm} / \mathrm{kg}$ seed + spaying of chlorpyriphos $2 \mathrm{ml} / \mathrm{liter}$ water 20 days after crop emergence) and Module 11(Seed treatment with clothianidin $2 \mathrm{gm} / \mathrm{kg}$ seed + application of clothianidin granules $200 \mathrm{gm} / \mathrm{ha} 20$ days after crop emergence) had statistically comparable ability to repress the \% affected plants to 4.5 and $6.0 \%$, respectively and were significantly superior over rest. The control plot registered highest percentage $(23.1 \%)$ of affected plants.

20 days after application of second treatment of the module: Plants affected by Gonocephalum adults, 20 days after application of second treatment of modules was in the range of $5.8-32.3 \%$ (Table 3 ). The lowest damage was recorded in Module 9 (Seed treatment with clothianidin $2 \mathrm{gm} / \mathrm{kg}$ seed + spraying of chlorpyriphos $2 \mathrm{ml} / \mathrm{liter}$ water 20 days after crop emergence) and was in turn at par with Module 10 (Application of phorate granules $10 \mathrm{~kg} / \mathrm{ha}$ at sowing + spaying of chlorpyriphos $2 \mathrm{ml} /$ liter water 20 days after crop emergence) with 5.8 and $6.2 \%$ affected plants, respectively, whereas, the control plot had highest percentage $(32.3 \%)$ of affected plants.

Per cent plants drying due to Gonocephalum injury 20 days after application of first treatment of the module: The \% dried plants due to Gonocephalum injury was in the range of $3.9-13.4 \%$ (Table 4) with 
Table .1 Details of various modules and cost of plant protection for the management of Gonocephalum.

\begin{tabular}{|c|c|c|c|c|c|c|}
\hline $\begin{array}{l}\text { Mod- } \\
\text { ule }\end{array}$ & Module details & $\begin{array}{l}\text { Cost of } \\
\text { insecti- } \\
\text { cide } \\
(\mathrm{Rs}) / \\
\mathrm{kg} / \mathrm{l}\end{array}$ & $\begin{array}{l}\text { Cost of } \\
\text { insecti- } \\
\text { cide per } \\
\text { ha }(\mathbf{R s})\end{array}$ & $\begin{array}{l}\text { Cost } \\
\text { of } \\
\text { mod- } \\
\text { ule } \\
(\text { Rs })\end{array}$ & $\begin{array}{l}\text { La- } \\
\text { bour } \\
@ \text { Rs. } \\
\text { 120/ } \\
\text { day }\end{array}$ & $\begin{array}{l}\text { Appli- } \\
\text { cation } \\
\text { cost of } \\
\text { mod- } \\
\text { ule } \\
\end{array}$ \\
\hline 1 & Seed treatment with chlorpyriphos $20 \mathrm{EC} @ 5 \mathrm{ml} / \mathrm{kg}$ seed & 270 & 90 & 90 & 0 & 90 \\
\hline 2 & Seed treatment with clothianidin 50 WDG @ $2 \mathrm{gm} / \mathrm{kg}$ seed & 14000 & 1680 & 1680 & 0 & 1680 \\
\hline 3 & $\begin{array}{l}\text { Application of clothianidin granules } 50 \text { WDG @ } 200 \text { gm/ha at } \\
\text { sowing }\end{array}$ & 14000 & 2800 & 2800 & 120 & 2920 \\
\hline 4 & Application of phorate granules $10 \mathrm{G} @ 10 \mathrm{~kg} / \mathrm{ha}$ at sowing & 55 & 550 & 550 & 120 & 670 \\
\hline 5 & $\begin{array}{l}\text { Spaying of chlorpyriphos } 20 \mathrm{EC} @ 2 \mathrm{ml} / \text { liter water } 20 \text { days after } \\
\text { crop emergence }\end{array}$ & 270 & 270 & 270 & 360 & 630 \\
\hline 6 & $\begin{array}{l}\text { Application of clothianidin granules } 50 \text { WDG @ } 200 \text { gm/ha } 20 \\
\text { days after crop emergence }\end{array}$ & 14000 & 2800 & 2800 & 120 & 2920 \\
\hline 7 & $\begin{array}{l}\text { Application of phorate granules } 10 \mathrm{G} @ 10 \mathrm{~kg} / \mathrm{ha} 20 \text { days after } \\
\text { crop emergence }\end{array}$ & 55 & 550 & 550 & 120 & 670 \\
\hline 8 & $\begin{array}{l}\text { Seed treatment with chlorpyriphos } 20 \mathrm{EC} @ 5 \mathrm{ml} / \mathrm{kg} \text { seed fol- } \\
\text { lowed by } \\
\text { spaying of chlorpyriphos } 20 \mathrm{EC} @ 2 \mathrm{ml} / \mathrm{liter} \text { water } 20 \text { days after } \\
\text { crop emergence }\end{array}$ & $\begin{array}{l}270 \\
270\end{array}$ & $\begin{array}{l}90 \\
270\end{array}$ & 360 & 360 & 720 \\
\hline 9 & $\begin{array}{l}\text { Seed treatment with clothianidin } 50 \text { WDG @ } 2 \text { gm } / \mathrm{kg} \text { seed fol- } \\
\text { lowed by } \\
\text { spaying of chlorpyriphos } 20 \mathrm{EC} @ 2 \mathrm{ml} / \text { liter water } 20 \text { days after } \\
\text { crop emergence }\end{array}$ & $\begin{array}{l}14000 \\
270\end{array}$ & $\begin{array}{l}1680 \\
270\end{array}$ & 1950 & 360 & 2310 \\
\hline 10 & $\begin{array}{l}\text { Application of phorate granules } 10 \mathrm{G} @ 10 \mathrm{~kg} / \mathrm{ha} \text { at sowing } \\
\text { followed by } \\
\text { spaying of chlorpyriphos } 20 \mathrm{EC} @ 2 \mathrm{ml} / \mathrm{liter} \text { water } 20 \text { days after } \\
\text { crop emergence }\end{array}$ & $\begin{array}{l}55 \\
270\end{array}$ & $\begin{array}{l}550 \\
270\end{array}$ & 820 & 480 & 1300 \\
\hline 11 & $\begin{array}{l}\text { Seed treatment with clothianidin } 50 \text { WDG @ } 2 \text { gm } / \mathrm{kg} \text { seed fol- } \\
\text { lowed by } \\
\text { application of clothianidin granules 50 WDG @ } 200 \text { gm/ha } 20 \\
\text { days after crop emergence }\end{array}$ & 14000 & $\begin{array}{l}1680 \\
2800\end{array}$ & 4480 & 120 & 4600 \\
\hline 12 & Control & - & - & - & - & - \\
\hline
\end{tabular}

lowest \% drying in Module 3 (Application of clothianidin granules $200 \mathrm{gm} / \mathrm{ha}$ at sowing) which had statistically comparable effect with application of Module 4 (Application of phorate granules $10 \mathrm{~kg} / \mathrm{ha}$ at sowing), Module 9 (Seed treatment with clothianidin $2 \mathrm{gm} / \mathrm{kg}$ seed) and Module 2 (Seed treatment with clothianidin 2 $\mathrm{gm} / \mathrm{kg}$ seed) with 3.9, 4.6, 4.7 and $5.0 \%$ drying of plants, whereas, untreated plot had $13.4 \%$ drying of plants.

20 days after application of second treatment of the module: During this phase the $\%$ dried plants due to injury was in the range of $3.8-18.2 \%$ (Table 4 ) with lowest \% drying in Module 9 (Seed treatment with Clothianidin $2 \mathrm{gm} / \mathrm{kg}$ seed + Spaying of chlorpyriphos $2 \mathrm{ml} /$ liter water 20 days after emergence) with $3.8 \%$ dried plants. Module 10 (Application of phorate granules $10 \mathrm{~kg} / \mathrm{ha}$ at sowing + spaying of chlorpyriphos 20 $\mathrm{ml} /$ liter water 20 days after emergence) and Module 11 (Seed treatment with clothianidin $2 \mathrm{gm} / \mathrm{kg}$ seed + application of clothianidin granules $200 \mathrm{gm} / \mathrm{ha} 20$ days after emergence) were the next effective modules with 4.3 and $4.6 \%$ drying of plants and were at par with the superior treatment. Highest loss of plant population was evident in control plot, indicating damage potential of the pest.

Yield: Data in Table 5 revealed superiority trend of Module 9 (Seed treatment with clothianidin $2 \mathrm{gm} / \mathrm{kg}$ seed + spaying of chlorpyriphos $2 \mathrm{ml} /$ liter water 20 days after crop emergence) and Module 11(Seed treatment with clothianidin $2 \mathrm{gm} / \mathrm{kg}$ seed + application of clothianidin granules $200 \mathrm{gm} / \mathrm{ha} 20$ days after crop emergence) in case of chickpea yield with yield level of 20.4 and $19.7 \mathrm{q} / \mathrm{ha}$ and were statistically at par. Application of Module 3 (Application of clothianidin granules $200 \mathrm{gm} / \mathrm{ha}$ at sowing) was next in order of ability to translate into higher yield and was at par with Module 6 (Application of clothianidin granules $200 \mathrm{gm} / \mathrm{ha} 20$ days after crop emergence) and Module 10 (Application of phorate granules $10 \mathrm{~kg} / \mathrm{ha}$ at sowing + spaying of chlorpyriphos $2 \mathrm{ml} /$ liter water 20 days after emergence) with yield of 17.8, 17.3 and $17.2 \mathrm{q} / \mathrm{ha}$, respectively. Lowest yield was recorded in control plot (13.2 q/ha).

Net profit and ICBR: Higher net returns (Table 5) were realized due to application of Module 9 (Seed treatment with clothianidin $2 \mathrm{gm} / \mathrm{kg}$ seed + spaying of chlorpyriphos $2 \mathrm{ml} /$ liter water 20 days after crop emergence), Module 11(Seed treatment with clothianidin 2 $\mathrm{gm} / \mathrm{kg}$ seed + application of clothianidin granules 200 gm/ha 20 days after crop emergence) and Module 10 (Application of phorate granules $10 \mathrm{~kg} / \mathrm{ha}$ at sowing + spaying of chlorpyriphos $2 \mathrm{ml} /$ liter water 20 days after 


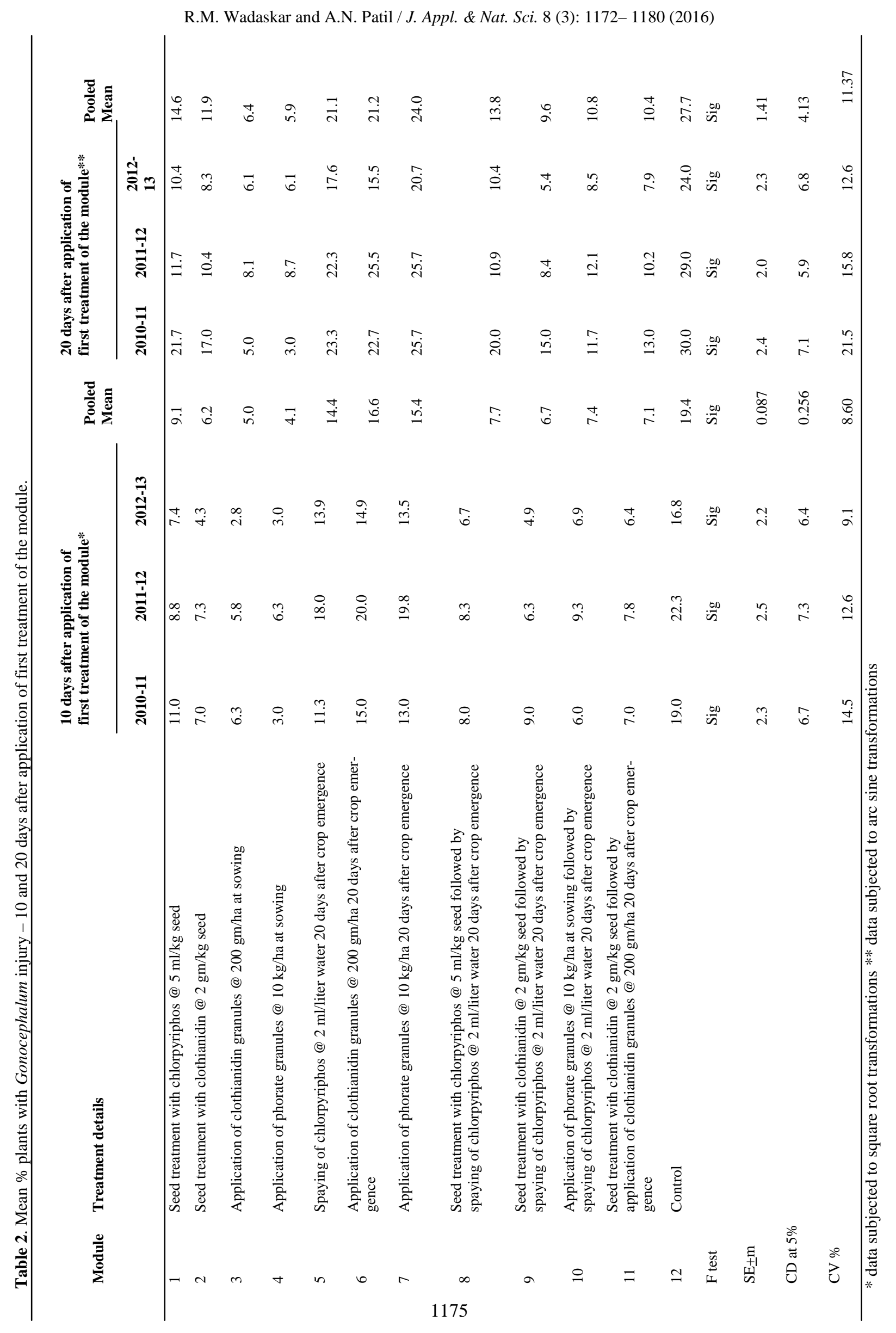




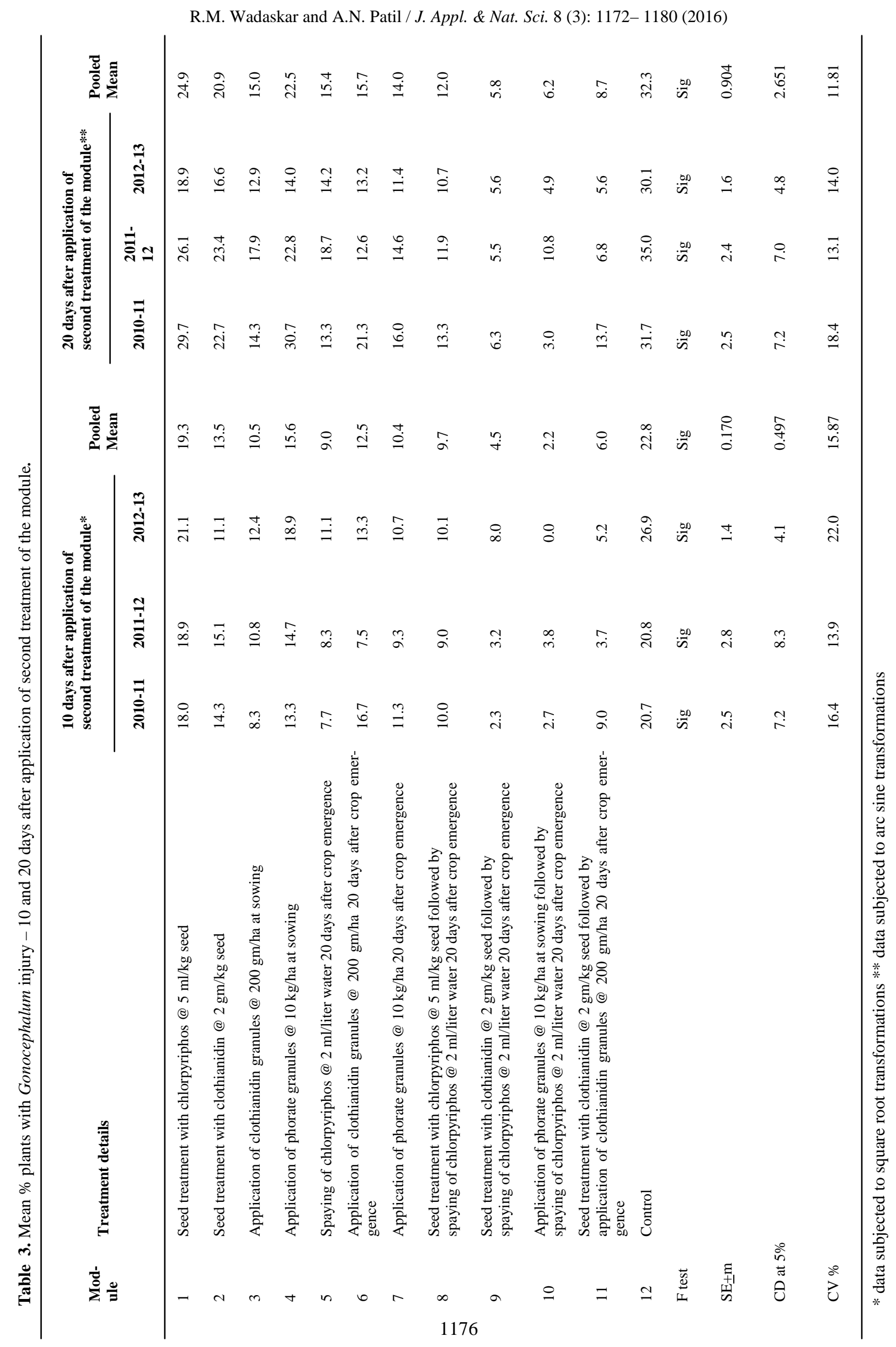




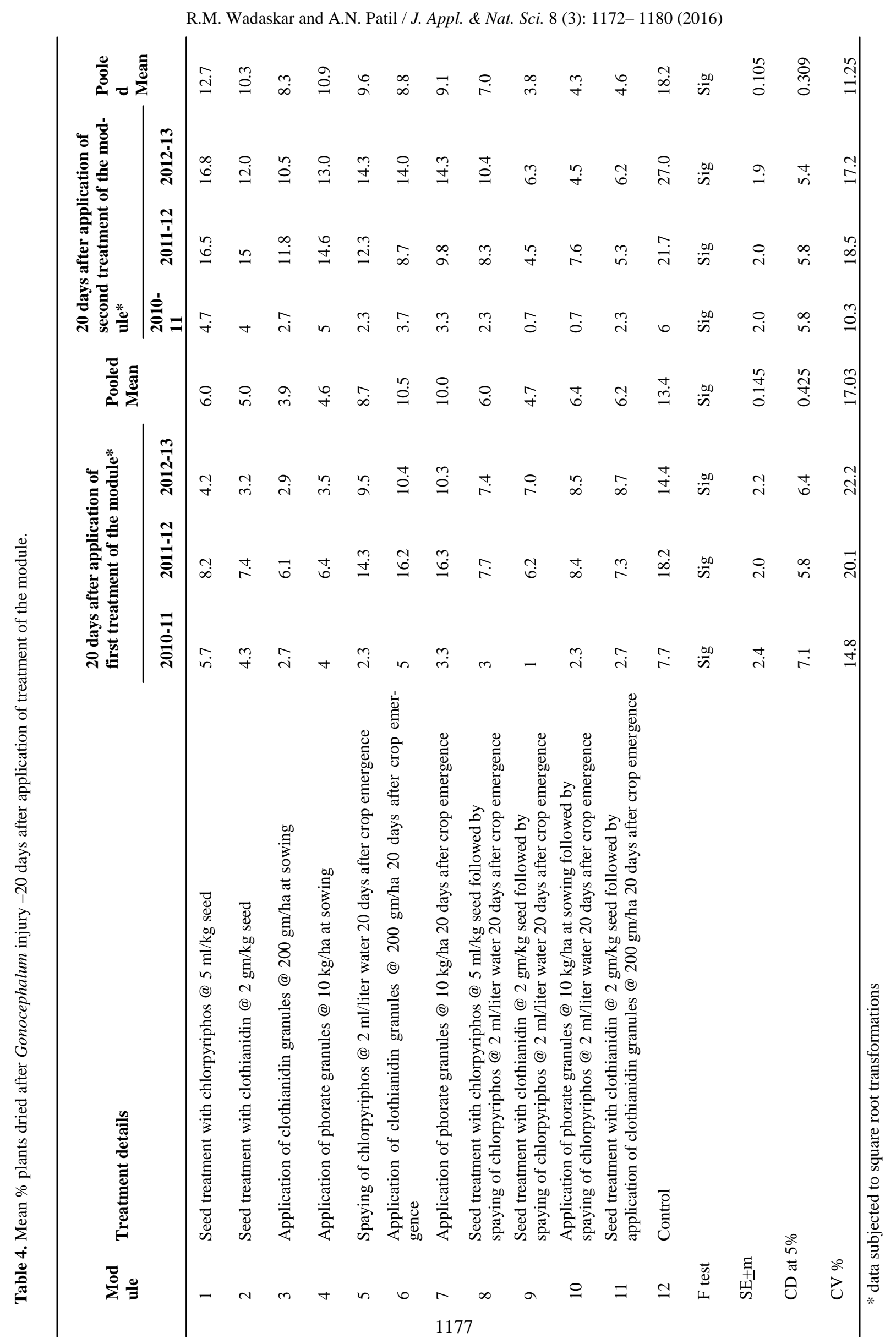


R.M. Wadaskar and A.N. Patil / J. Appl. \& Nat. Sci. 8 (3): 1172- 1180 (2016)

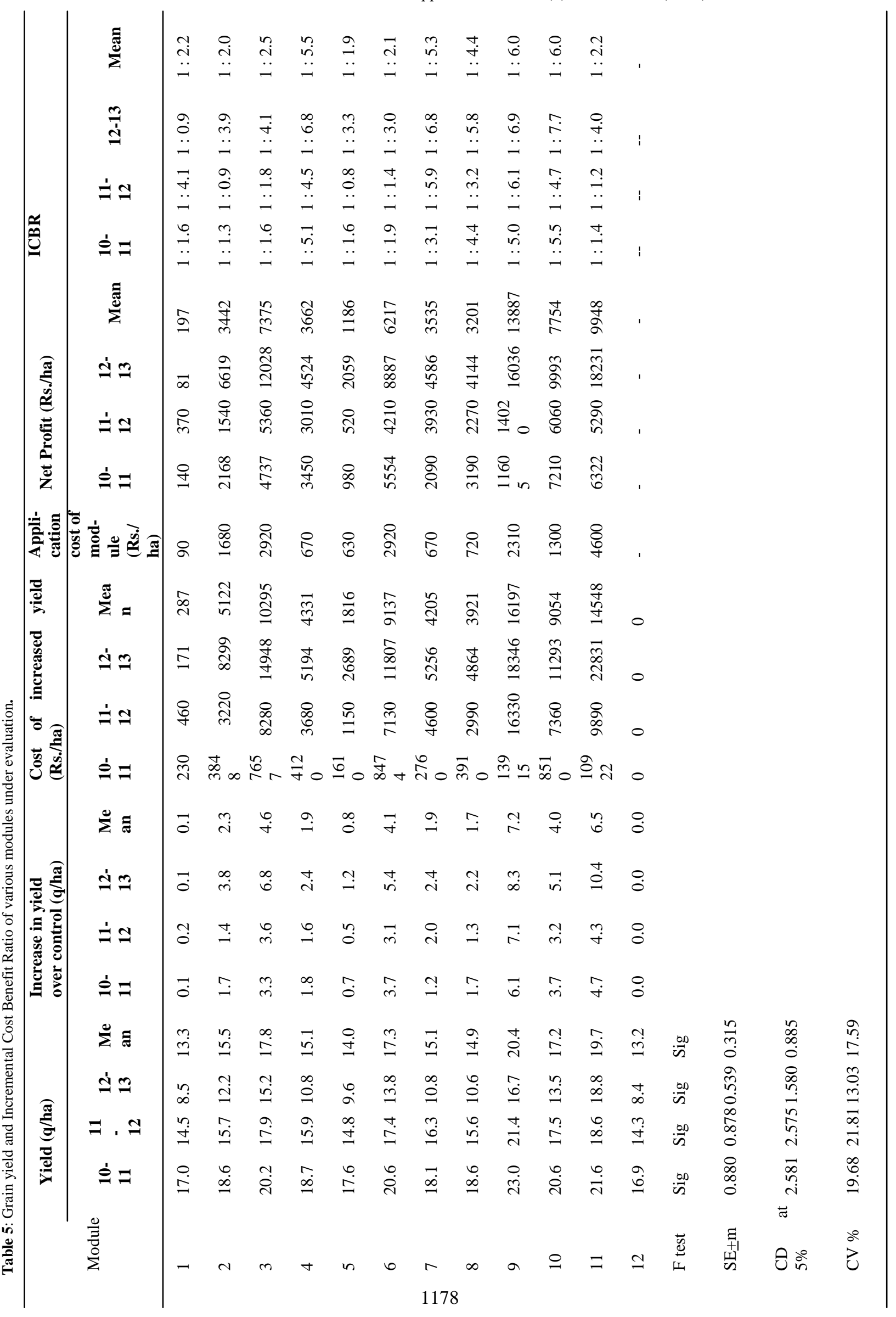


crop emergence) with Rs. 13887, Rs. 9948 and Rs. 7754 per ha, respectively. Lowest net returns were realized due to application of Module 1 (Seed treatment with chlorpyriphos $5 \mathrm{ml} / \mathrm{kg}$ seed) with $197 \mathrm{Rs} / \mathrm{ha}$. In terms of Incremental Cost Benefit Ratio (Table 5), application of Module 9 (Seed treatment with clothianidin $2 \mathrm{gm} / \mathrm{kg}$ seed + spaying of chlorpyriphos $2 \mathrm{ml} /$ liter water 20 days after crop emergence), Module 10 (Application of phorate granules $10 \mathrm{~kg} / \mathrm{ha}$ at sowing + spaying of chlorpyriphos $2 \mathrm{ml} /$ liter water 20 days after crop emergence) had higher ICBR of 1:6.0. It was followed by application of Module 4 (Application of phorate granules $10 \mathrm{~kg} / \mathrm{ha}$ at sowing) and Module 7 (Application of phorate granules $10 \mathrm{~kg} / \mathrm{ha} 20$ days after crop emergence) with ICBR of 1:5.5 and 1:5.3, respectively. Although, treatments with application of clothianidin granules revealed more field efficacy, they lagged in cost effectiveness parameter on the basis of higher cost of insecticide.

Although, present findings could not be compared for the want of literature, review suggest Clothianidin is a novel neonicotinoid insecticide acting as an agonist of nicotinic acetylcholine receptor (nAChR). Clothianidin is highly active against coleopterous pests,since it possesses excellent root systemic properties (Ohkawara et $a l ., 2002)$. Clothianidin has been extensively used for seed treatment against major insect pests of maize, canola and other crops. The compound enters the transpiration stream through the roots of newly germinating seedlings and developed plants. Pests become intoxicated mainly through ingestion of protected plant tissues and stop feeding immediately (Schwarz et al., 2002). In field trials, clothianidin exhibited excellent control of insect pests by soil application and seed treatment. In tests for control of corn rootworm (Diabrotica spp.), clothianidin demonstrated a consistent reduction of root damage. Clothianidin also showed excellent control of most important secondary pests of maize when used as seed treatment. The compound has good activity against wireworm (Melanotus spp.), seed corn maggot (Hylemya platura [Delia platura]), flea beetle (Chaetocnema pulicaria) and white grub (Lachnosterna implicita [Phyllophaga implicita]). The compound also showed good activity for black cutworm (Agrotis ypsilon [Agrotis ipsilon]). Control of corn rootworm and secondary pests resulted in a significant increase in yield up to $17.6 \%$ on the average compared to the control plots (Schwarz et al., 2002), thus supporting the present findings

Thiamethoxam, the neonicotinoid was found efficient in control of all important soil-dwelling and early leaffeeding pests like wireworms, false wireworms, flea beetles, pea weevils, colorado potato beetles. Hofer et al. (2001) also confirmed the utility of neonicotinoides in management of false wireworms. Also the reports of efficacy of clothianidin against turf pests, termites and white grubs strengthen the present findings.

Chloropyriphos is also an effective insecticide for soil borne pest viz., termites on account of its contact and fumigant action. The use of insecticides viz., chlorpyrifos, terbufos, furathiocarb and thiodicarb in the control of false wireworms is recommended by Robertson, 1993 which is in corroboration with present outcome.

\section{Conclusion}

From the present study it can be concluded that Seed treatment with clothianidin $2 \mathrm{gm} / \mathrm{kg}$ seed followed by spaying of chlorpyriphos $2 \mathrm{ml} /$ liter water, 20 days after crop emergence and Application of phorate granules $10 \mathrm{~kg} / \mathrm{ha}$ at sowing followed by spraying of chlorpyriphos $2 \mathrm{ml} /$ liter water, 20 days after crop emergence were most promising modules in terms of lower $\%$ damaged plants, higher yield, higher net money returns and higher cost effectiveness and can be recommended for the management of Gonocephalum in chickpea.

\section{ACKNOWLEDGEMENTS}

Authors are thankful to Dr. V.V. Ramamurthy, National Coordinator, Network Project on Insect Biosystematics, Entomology Division, Indian Agriculture Research Institute, New Delhi.

\section{REFERENCES}

Blair, B.W. (1990). Insect and mite pests of tobacco in Zimbabwe: description, biology and damage. Booklet by Tobacco Research Board, Harare, Zimbabwe. pp. 17.

Drinkwater, T.W. (1989). Occurrence of soil-inhabiting Tenebrionidae (Coleoptera) in maize fields in South Africa. Phytophylactica, 21(4):397-398.

Drinkwater, T.W. (1999). Regional distribution of Gonocephalum species (Coleoptera: Tenebrionidae) in maize fields in South Africa. African Entomology, 7(2):183-187.

Hofer, D., Brandl, F., Druebbisch, B., Doppmann, F., Zang, L and Biddle, A.J. (2001). Thiamethoxam - a novel insecticide for seed delivered insect control. Seedtreatment:-challenges-and-opportunities. In Proceedings of an international Symposium, Wishaw, North Warwickshire -UK, -26-27-February-2001.

Kapadia, M.N. (1994). Record of three false wireworms infesting groundnut in Gujarat. Gujarat Agricultural University Research Journal, 19(2):128-129.

Miles, M., Allsopp, P.G., Rogers, D.J. and Robertson, L.N. (1997). False wireworm: an emerging pest of canola in Victoria's Wimmera. Soil invertebrates in Proceedings of the 3rd Brisbane Workshop on Soil Invertebrates. pp. 138139.

Ohkawara, Y., Akayama, A., Matsuda, K. and Andersch, W. (2002). Clothianidin: a novel broad-spectrum neonicotinoid insecticide. In The BCPC Conference: Pests and diseases, Volumes 1 and 2. Proceedings of an international conference held at the Brighton Hilton Metropole Hotel, Brighton, UK, 18-21 November 2002, pp. 51-58.

Reddy, M.V., Kumar, V.P.K. and Reddy, B.K. (1992). Occurrence of Gonocephalum sp. (Tenebrionidae: Coleop- 
R.M. Wadaskar and A.N. Patil / J. Appl. \& Nat. Sci. 8 (3): 1172- 1180 (2016)

tera) as a pest of groundnut in India. Tropical Pest Management, 38(1):108.

Robertson, L.N. (1993). Population dynamics of false wireworms (Gonocephalum macleayi, Pterohelaeus alternatus, $P$. darlingensis) and development of an integrated pest management program in central Queensland field crops: a review. Australian Journal of Experimental Agriculture, 33(7):953-962.

Schwarz, M., Christie, D., Andersch, W., Kemper, K., Fellmann, K. and Altmann, R. (2002). Control of corn rootworms (Diabrotica spp.) and of secondary pests of corn (Zea mays) using seed treatments of clothianidin. In The BCPC Conference: Pests and diseases, Volumes 1 and 2. Proceedings of an international conference held at the Brighton Hilton Metropole Hotel, Brighton, UK, 18-21 November 2002, pp. 59-64.

Umeh, V.C., Youm, O. and Waliyar, F. (2001). Soil pests of groundnut in sub-Saharan Africa - a review. Insect Science and its Application, 21(1): 23-32. 